\title{
Glikojen Depolarının ve Sıvı Besin Alımının Egzersiz Sırasında Yağ ve Karbonhidrat Kullanımina Etkisi
}

\author{
Effect of Glycogen Stores and Liquid Food Intake on Fat and Carbohydrate Utilization During \\ Exercise
}

\section{Süleyman Bulut ${ }^{1}$, Hüsrev Turnagöl ${ }^{2}$}

Geliş tarihi/Received: 23.10.2017 • Kabul tarihi/Accepted: 02.04.2018

\section{ÖZET}

Amaç: Açlık durumunun yağ metabolizmasını aktive ettiği iyi bilinmektedir. Bunun yanında son yıllarda, egzersize düşük kas glikojen depoları ile başlamanın normal duruma göre yağ metabolizmasını daha iyi aktive ettiği ve antrenmana daha fazla adaptasyon sağladığı ile ilgili çalışmalar artmıştır. Bu çalışma, düşük kas glikojen depoları ile egzersiz yapılmasının yağ metabolizmasını daha fazla etkileyip etkilemediğini test etmek için planlanmış ve yapılmıştır.

Bireyler ve Yöntem: Araştırmaya 9 erkek, triatlon sporcusu katılmıştır. Bir hafta ara ile, kahvaltıda sıvı besin verilen veya aç (1 gece) durumda egzersiz denemeleri dengeli randomize, çapraz dizaynda gerçekleştirilmiştir. Çalışma öncesi tüm katılımcılar $\mathrm{VO}_{2}$ zirve ve zirve güç değerlerinin belirlenmesi için $\mathrm{VO}_{2}$ zirve testine katılmışlardır. Katılımcılar her iki durumda (Sıvı besin Egzersiz: SE1, SE2 ve Aç Egzersiz: AE1, AE2) \%70 VO zirve'de $60 \mathrm{dk}$ süren iki egzersiz denemesini 1 saat dinlenme aralığı ile yapmışlardır. Böylece ikinci egzersiz denemelerinin düşük kas glikojeni ile yapılması hedeflenmiştir.

Bulgular: Toplam yağ oksidasyonu, SE1-SE2 (13.4 $\pm 6.7 \mathrm{~g} / 60 \mathrm{dk}$ ve $23.9 \pm 7.6 \mathrm{~g} / 60 \mathrm{dk}, \mathrm{p}<0.001)$ ve SE1-AE2 $(13.4 \pm 6.7 \mathrm{~g} / 60 \mathrm{dk}$ ve $27.4 \pm 6.0 \mathrm{~g} / 60 \mathrm{dk}, \mathrm{p}=0.002)$ egzersizleri arasında anlamlı derecede artmıştır.

Sonuç: Bu araştırma kapsamında bir gece açlık sonrası düşük kas glikojen depoları ile yapılan egzersizin sıvı besin alınan durumda yapılana göre yağ metabolizmasının arttırılmasında daha fazla bir etkinliğinin olmadığı belirlenmiştir. Bu bulgular, yağ metabolizmasındaki etkinliği arttıran esas belirleyici etmenin karaciğer glikojen depolarından çok kas glikojen depolarınının seviyesi olduğunu göstermektedir.

Anahtar kelimeler: $V_{2}$ zirve, yağ, RER, karbonhidrat

\section{ABSTRACT}

Aim: It is well known that fasting activates fat metabolism. Besides, in recent years many research studies accumulated that commencing exercise with low muscle glycogen is an effective strategy to activate fat metabolism and gain more training adaptation than normal muscle glycogen state. To test whether exercise with low glycogen stores is superior to activate fat metabolism we set up this study.

Subjects and Methods: Nine male triathletes participated in this study. Consumption of liquid food breakfast or fasted (overnight) exercise trials were done separated by one week intervals with crossover, counterbalanced randomized design.

1. Hacettepe Üniversitesi, Spor Bilimleri Fakültesi, Egzersizde Beslenme ve Metabolizma Anabilim Dalı, Ankara, Türkiye

(ㄱ https://orcid.org/0000-0001-6831-6608
2. ̇letişim/Correspondence: Hacettepe Üniversitesi, Spor Bilimleri Fakültesi, Egzersizde Beslenme ve Metabolizma Anabilim Dalı, Ankara, Türkiye • E-posta: husrevturnagol@gmail.com

으 https://orcid.org/0000-0001-6547-8839 
Prior to the study all the subjects attended to maximal exercise test to determine $\mathrm{VO}_{2}$ peak and peak power output (PPO). For both trial subjects attended to two 60 min exercise sessions at $70 \% \mathrm{VO}_{2}$ peak (Liquid food Exercise: LE1, LE2 or Fasted Exercise: FE1, FE2) with one hour resting period, thus the second exercise period aimed to be performed with low muscle glycogen stores.

Results: Total fat oxidation in LE1 was significantly higher than both LE2 (LE1-LE2; 13.4 $\pm 6.7 \mathrm{~g} / 60 \mathrm{~min}$ versus 23.9 $\pm 7.6 \mathrm{~g} / 60$ min, $p<0.001$ ) and FE2 (LE1-FE2; $13.4 \pm 6.7 \mathrm{~g} / 60$ min versus $27.4 \pm 6.0 \mathrm{~g} / 60 \mathrm{~min}, \mathrm{p}=0.002$ ).

Conclusion: In conclusion we found that there is no superior effect of overnight fasted state exercise with depleted muscle glycogen stores over liquid food given counterpart to increase fat metabolism. Furthermore, it seems that, the major determinant improving fat metabolism in this study is the state of muscle glycogen stores rather than the level of liver glycogen stores.

Keywords: $\mathrm{VO}_{2}$ peak, fat, RER, carbohydrate

\section{Gíriş}

Egzersiz öncesinde karbonhidrat depolarının değişmesini sağlayan etkenler açlık ve besin tüketim durumlarıdır. Bir gece açlık sonrasında yapılan egzersizin başlıca yakıt olarak karbonhidratlar yerine yağları kullanmayı sağladığı ve böylece vücut yağ yüzdesiniazaltmada daha etkin olduğunu ortaya koyan çalışmalar bulunmaktadır (1,2). Diğer taraftan açlığın dayanıklılık performansında azalmaya yol açtığı da gözlenmiştir (3-5). Ancak performansta meydana gelen bu düşüşlerin, katılımcılara uzun süreli açlık periyodu (>24 saat) uygulanmasından, yorgunluğa ulaşıncaya kadar egzersiz yaptırılmasından veya egzersiz şiddetinin yüksek olmasından kaynaklanabileceği belirtilmektedir (6). Nitekim kısa süreli açlık (11-24 saat) durumunda uygulanan dayanıklılık egzersizinin insan (7) ve hayvan (8) çalışmalarında performansta azalma oluşturmadığı belirlenmiştir. Uzun süreli açlık durumunda gerçekleştirilen egzersiz sırasında, serbest yağ asitleri düzeyinin artmasının glikojen kullanımını azalttığı ve bu durumun performansta gözlenen düşüşün sebebi olabileceği ileri sürülmüştür $(8,9)$. Aslında, bir gece açlık sonrasında yapılan akut egzersiz sırasındaki yağ asidi yakımının, egzersiz öncesinde ve sirasında karbonhidrat alımı gerçekleştirilen egzersizlere göre daha yüksek olduğu bilinmektedir (10). Aynı zamanda, bir gece açlık sonrasında yaptırılan akut dayanıklılık egzersizi sırasında karbonhidrat tüketiminin yağların oksidasyonu ile ilgili gen ekspresyonlarını baskıladığı rapor edilmiştir (11).
İnsanlarda karaciğer ve/veya kas glikojen depolarının içeriğini manipüle ederek akut dayanıklılık egzersizinin hormonal ve metabolik etkilerini inceleyen çalışma sayısı oldukça azdır $(12,13)$. Bu insan çalışmalarında aç durumda antrenmanın ve akut besin-sıvı kısıtlmasının egzersiz performansını geliştirici, metabolik yakıt olarak yağ kullanımını arttırıcı etkileri kayıt edilmiştir $(12,13)$. Hayvanlarda düşük karaciğer glikojeni düzeyinin, egzersiz sırasında yağ dokusundan serbest yağ asidi salınımını arttırdığı gözlenmiştir (14). Bu noktadan hareketle, açlığa bağlı olarak karaciğer, egzersize bağlı olarak ise kas glikojeni seviyelerinin düşürülmesinin insanlarda da egzersiz sırasında yağ asidi serbestlenmesini arttırabileceği ve kas hücrelerinde yağ yakımına yönelik metabolik adaptasyonlar yaratabileceği düşünülebilir. Yukarıda belirtilen bilgiler ışığında açlık, tokluk, egzersiz, dinlenme ve beslenme gibi etkenler vücut enerji durumunu ve başlıca karbonhidrat depolarının miktarını değiştirebilmektedir $\quad(2-4,7-10,12) . \quad \mathrm{Bu}$ noktada glikojen depolarının miktarının artıp azalması ile meydana gelen değişimlerin egzersiz metabolizmasını farklı olarak etkileyebileceği öngörülebilir.

Bu çalışmanın temel amacı, düşük karaciğer ve/veya kas glikojen depolarının, akut dayanıklılık egzersizi sırasında yakıt (karbonhidrat ve yağ) kullanımına etkisini karşılaştırmaktır. Bu amaçla, bir hafta ara ile açlık (10-12 saat) ve tokluk (sıvı besin ile kahvaltı) 
gibi iki farklı metabolik koşulda, 1 saat dinlenme aralığı ile tekrarlanan aynı şiddetteki iki akut dayanıklılık egzersizi planlanmıştır. Bir gece açlığı takiben planlanan egzersiz denemesi düşük karaciğer depolarının, sıvı besin (kahvaltı) verilerek yapılan egzersiz denemesi ise karaciğer depolarının nispeten dolu olduğu metabolik koşulları temsil etmektedir. Aynı gün bir saat ara ile planlanan egzersizlerin amacı ise kas glikojen depolarını manipüle etmektir. Birinci egzersizin kas glikojen depoları nispeten doluyken, ikinci egzersizin ise daha düşük kas glikojen depoları ile (birinci egzersiz sirasında kas glikojen depoları kullanıldığından) gerçekleştirilmesi hedeflenmiştir. Böylece karaciğer ve/veya kas glikojen depolarının egzersiz sirasinda yakıt metabolizmasını nasıl etkilediğinin incelenmesi amaçlanmıştır.

\section{BİREYLER VE YÖNTEM}

\section{Katılımcılar ve Özellikleri}

$\mathrm{Bu}$ çalışmaya yaşları 21.5 \pm 2.06 yıl (19-26 yıl), boy uzunlukları $176.1 \pm 4.79 \mathrm{~cm} \quad(167-181.5 \mathrm{~cm}$ arasında) olan 9 erkek triatlon sporcusu katılmıştır (Tablo 1). Çalışma, dengeli randomize ve çapraz dizaynda gerçekleştirilmiştir. Sporcular, çalışmada gerçekleştirilecek işlemlerin risklerinin kendilerine detaylı bir şekilde açıklanmasını takiben bilgilendirilmiş onam formlarını imzalayarak araştırmaya gönüllü olarak katılmışlardır. Bu çalışma Hacettepe Üniversitesi "Girişimsel olmayan klinik araştırmalar etik kurulu” tarafindan kabul edilmiş (Karar no: GO 13/206-07-2013) ve araştırma kapsamındaki tüm işlemler Helsinki Deklerasyonuna uygun gerçekleştirilmiştir.

Tablo 1. Sporcuların antropometrik özellikleri

\begin{tabular}{lc}
\hline Özellikler & $\overline{\mathrm{X}} \pm \mathbf{S}$ \\
\hline Yaş (yll) & $21.5 \pm 2.06$ \\
Boy uzunluğu (cm) & $174.9 \pm 4.40$ \\
Vücut ağırlığı (kg) & $65.9 \pm 3.30$ \\
BKİ $\left(\mathrm{kg} / \mathrm{m}^{2}\right)$ & $21.6 \pm 1.59$ \\
Vücut yağ yüzdesi (\%) & $7.8 \pm 2.36$ \\
Vücut yağ ağırlığı (kg) & $5.2 \pm 1.64$ \\
Yağsız kas ağırlığı $(\mathrm{kg})$ & $60.7 \pm 2.79$ \\
\hline
\end{tabular}

BKİ: Beden Kütle İndeksi

\section{Araştırma Planı}

Çalışmadan 1 hafta önce katılımcıların zirve oksijen tüketimleri, zirve güç değerleri ve vücut bileşimleri ölçülmüştür. Bu ölçümler öğlen 11.00-15.00 saatleri arasında postprandial olarak yapılmıştır. Zirve egzersiz testinde elde edilen zirve oksijen tüketimi $\left(\mathrm{VO}_{2}\right.$ zirve) ve zirve güç değerleri egzersiz denemelerinin şiddetinin belirlenmesinde kullanılmıştır.

Egzersiz denemeleri: Katılımcllar laboratuvara birer hafta ara ile birinde sıvı besin alarak (2 saat postprandial) ve diğerinde 1 gece açlık sonrası (1012 saat) olmak üzere iki defa egzersiz denemelerini gerçekleştirmek için çağrılmışlardır. Katılımcılara, her iki metabolik koşulda (sıvı besin aldıkları durumda ve aç durumda) 1 saat dinlenme aralığı verilerek 60 dakikalık iki dayanıklılık egzersizi uygulanmıştır. Egzersizler öncesinde dinlenik olarak ve egzersiz sirasinda bireylerin toplam soludukları hava toplanmış ve kaydedilmiştir. Ayrıca bireylerden her deney gününden önceki 48 saatlik besin tüketimlerini kaydetmeleri istenmiştir.

\section{Deney Öncesi Uygulanan Testler ve Ölçümler} Antropometrik ölçümler ve vücut bileşimi: Katılımclların boy uzunluğu, vücut ağırlığı, bel ve kalça ölçümleri sırası ile stadiometre (Holtain), gullik metresi ile antropometrik prosedürlere uygun bir şekilde ve vücut bileşimi ise elektronik tartı (Tanita TBF 300, Almanya) kullanılarak gerçekleştirilmiştir (15). Tüm ölçümler, "International Society for the Advancement of Kinanthropometry" ISAK I) seviye I antropometri belgesi bulunan aynı antropometrist tarafından yapılmıştır.

Zirve $\mathrm{VO}_{2}$ testi: Bütün katılımcılar çalışma öncesinde zirve güç ve zirve $\mathrm{VO}_{2}$ değerlerinin belirlenebilmesi için Monark 894E bisiklet ergometresinde (Monark Egzersiz, Varberg, İsveç) aşamalı artan $\mathrm{VO}_{2}$ zirve testine katılmışlardır. Zirve $\mathrm{VO}_{2}$ testi sırasında bireylerin kalp atım hızları polar saat (Polar 810i, Finlandiya), oksijen tüketimleri ise indirekt spirometre Quark b² (COSMED, Roma, İtalya) ile standart laboratuvar koşullarında (21-22 ${ }^{\circ} \mathrm{C}, \%$ 40-50 bağıl nem) ölçülmüştür. Her test 
öncesinde bilinen gaz konsantrasyonları (\%4.1 $\mathrm{CO}_{2}$, $\% 14.9 \mathrm{O}_{2}, \mathrm{~N}_{2}$ denge. The Linde Group, Lindegaz Ankara) ile Quark $b_{2}$ metabolik kart kalibre edilmiştir. Ekspire edilen hava akımmetre $\mathrm{O}_{2}$ ve $\mathrm{CO}_{2}$ analizörlerinden geçerek bağlı olduğu bilgisayardaki yazılım yardımı ile $\mathrm{O}_{2}$ alımı $\left(\mathrm{VO}_{2}\right)$ ve $\mathrm{CO}_{2}$ üretimi $\left(\mathrm{VCO}_{2}\right)$ ile solunum değişim katsayısı (RER) değerleri çevrimiçi olarak hesaplanmıştır. Zirve $\mathrm{VO}_{2}$ testi, 60 watt ile başlamış, her 150 s'de 30 watt artış ile bireysel yorgunluğa kadar devam etmiştir (16). Zirve $\mathrm{VO}_{2}$ testi, bireyin 60 devir/dk (rpm-round per minute) pedal hızını uyarıya rağmen 3 defadan fazla devam ettirememesi, kalp atım hızının “220-yaş” formülü ile hesaplanan maksimal kalp atım hızı değerine ( \pm 10 atım) ulaşması ve RER değerinin 1.05'in üzerinde olması koşullarından iki tanesinin gerçekleşmesi durumunda sonlandırılmıştır (17). Zirve $\mathrm{VO}_{2}$ değeri herhangi bir 30 sn'deki en yüksek oksijen tüketim değeri olarak alınmıştır. Zirve güç değeri ise daha önce kullanılan ve aşağıda verilen formüle göre hesaplanmıştır (18).

Wzirve $=$ Wfinal $+(\mathrm{t}=150) \times 30$ watt

Wzirve: Zirve güç, Wfinal: Tamamlanan son yük,

t: Tamamlanamayan son iş yükünde gidilen süre, saniye cinsinden

30 watt: Artış miktarı

Ayrıca her bireyin yük ve zirve oksijen tüketim değerlerinden, excel programı içerisinde birinci dereceden ekstrapolasyon (matematiksel kestirim) ile $\% 70 \mathrm{VO}_{2}$ zirve değerine karşılık gelen yük hesaplanmış ve egzersiz denemelerinde egzersiz şiddeti olarak bu yük kullanılmıştır.

Diyet ve antrenman: Katılımclarin egzersiz denemelerinden 48 saat önce antrenman veya egzersizleri kesmeleri, özellikle son 24 saat içerisinde kafein ve alkol alımından sakınmaları istenmiştir. Ayrıca açlık ve tokluk egzersiz denemeleri öncesinde katılımcıların 48 saatlik besin tüketimleri anabilim dalında görevli uzman spor diyetisyeni tarafından kaylt edilmiş ve Beslenme Bilgi Sistemi (BEBİS, Lisans no: 658560, Pasifik Ltd Company, Üsküdar, İstanbul) ile analiz edilerek enerji, karbonhidrat, protein ve yağ alımları hesaplanmıştır. Katılımcılardan bu süreç içerisinde diyetlerinde çok büyük değişiklikler yapmamaları ve her iki denemeye gelirken de benzer beslenmeleri istenmiştir (Tablo 3). Katılımcılara sıvı besin egzersiz denemesinden 2 saat önce standart olarak $10 \mathrm{kkal} / \mathrm{kg}$ enerji düzeyinde (\%57 karbonhidrat, \%15 protein, \%28 yağ, Ensure Plus, Abbott Nutrition Lab., Türkiye) sıvı besin verilmiştir. Egzersizler sırasında katılımcıların sadece su tüketmelerine izin verilmiş ve bunun dışında hiçbir şey tüketmemelerine dikkat edilmiştir.

Dayanıklılık egzersizleri: Katılımcllar zirve $\mathrm{VO}_{2}$ testi sonrasında 1 hafta ara ile aç iken ve sıvı besin almış durumda dayanıklılık egzersizlerini uygulamışlardır. Tüm ölçümler sabah 9.00-12.00 saatleri arasında gerçekleştirilmiştir. Her iki denemede de katılımcılar laboratuvara sabah $\quad 8.00-8.30$ saatleri arasinda gelmişlerdir. Katılımcılar aç denemede bir gece açlık (10-12 saat), sıvı besin alınan denemede ise sıvı besini tükettikten 2 saat sonra egzersiz testine başlamışlardır. Her iki denemede de (açlık durumu ve sıvı besin tüketilmiş olan durum), katılımcılar 1 saat dinlenme aralığı ile $\% 70 \mathrm{VO}_{2}$ zirve şiddetinde her biri $60 \mathrm{dk}$ süren 2 egzersizi Monark 894E bisiklet ergometresinde tamamlamışlardır. Böylece her iki durumda aynı şiddette (\%70 $\mathrm{VO}_{2}$ zirve) ikişer egzersizden olmak üzere toplamda dört egzersiz 1 hafta ara ile katılımcılara uygulanmıştır. Egzersize sıvı besin alınmış olarak başlanması ile karaciğer glikojen depolarının dolu durumda olması, egzersize aç başlanması ile ise karaciğer glikojen depolarının düşük düzeyde bulunması hedeflenmiştir. Ayrıca aç iken ve sıvı besin tüketilmiş durumda yapılan ilk egzersizler ile kas glikojen seviyelerinin düşürülmesi ve ikinci egzersizlerin daha düşük kas glikojen düzeyleri ile yapılması amaçlanmıştır. $\mathrm{Bu}$ egzersizlerin kısaltmaları şu şekilde belirtilmiştir:

SE1 = Sıvı besin alınmış durumdaki birinci egzersiz

SE2 = Sıvı besin alınmış durumdaki ikinci egzersiz

AE1= Bir gece açlık durumunda yapılan birinci egzersiz 
AE2= Bir gece açlık durumunda yapılan ikinci egzersiz

Katılımcllardan tüm egzersizler öncesi $10 \mathrm{dk}$ oturarak dinlenmenin ardından $5 \mathrm{dk}$ dinlenmeden sonra $\mathrm{VO}_{2}$ ölçümü yapılmış ve kayıt edilmiştir. Ayrıca tüm egzersiz denemeleri sırasında $\mathrm{VO}_{2}$ ölçümleri yapılmış ve kayıt edilmiştir. Yağ ve karbonhidrat oksidasyonları (g/dk) Frayn (19) protein oksidasyonu ihmal eden $\mathrm{VO}_{2}$ (tüketilen oksijen hacmi/L) ve $\mathrm{VCO}_{2}$ (üretilen karbondioksit hacmi/L) formülünden aşağıdaki gibi hesaplanmıştır:

Karbonhidrat oksidasyonu g/dk $=4.55 \mathrm{VCO}_{2}-3.21 \mathrm{VO}_{2}$ Yağ oksidasyonu g/dk $=1.67 \mathrm{VO}_{2}-1.67 \mathrm{VCO}_{2}$

\section{İstatistiksel Değerlendirme}

Verilerin analizi için SPSS 21.0 paket istatistik programı kullanılmıştır. Tüm verilerin ortalama \pm standart sapma $(\overline{\mathrm{X}} \pm \mathrm{S})$ değerleri verilmiş olup verilerin normal dağılımı kontrolü için Shapiro Wilk normallik testi uygulanmıştır. Normal dağılım gösteren veriler arasındaki farkı tespit etmek için ikili örneklerde eşleştirilmiş iki örnek t testi, çoklu tekrarlarda ise tekrarlı ölçümlerde tek yönlü varyans analizi (ANOVA) kullanılmıştır. İkiden fazla tekrarlı ölçümlerde fark bulunması halinde farkların hangi ölçüm çiftlerinden kaynaklandığını belirlemek için ise ANOVA için Bonferoni, Friedman için ise Wilcoxon testleri kullanılmıştır.

\section{BULGULAR}

Sporcuların antrenman yllları $3.3 \pm 1.34$ yll olarak belirlenmiştir. $\mathrm{VO}_{2}$ zirve değerleri $46.9 \pm 5.2$ (mL/kg/ $\mathrm{dk}$ ) olarak kayıt edilmiştir. Zirve $\mathrm{VO}_{2}$ testi sırasında ulaşılan en yüksek kalp atım hızları (Maks KAH) 195.4 \pm 3.2 atım/dk olarak saptanmıştır (Tablo 2).

Tablo 2. Egzersiz kapasitesi ve antrenman durumu bilgileri

\begin{tabular}{lc}
\hline Özellikler & $\overline{\mathrm{X}} \pm \mathbf{S}$ \\
\hline Antreman yıll (yıl) & $3.4 \pm 1.4$ \\
$\mathrm{VO}_{2}$ zirve $(\mathrm{mL} / \mathrm{kg} / \mathrm{dk})$ & $46.9 \pm 5.2$ \\
Maks KAH (atım/dk) & $195.8 \pm 3.2$ \\
\hline Zirve $\mathrm{VO}_{2}:$ Zirve Oksijen Tüketimi, Maks KAH: Maksimum Kalp Atım Hızı
\end{tabular}

Besin tüketim analizi sonuçlarına göre, katılımcıların sıvı besin alınan ve aç durumda gerçekleştirilen egzersiz testlerinden 48 saat öncesine kadar geçen sürede aldıkları günlük enerji, karbonhidrat, yağ ve protein ortalamaları arasinda anlamlı fark yoktur (Tablo 3). Günlük ortalama karbonhidrat tüketim miktarları, sıvı besin alınan egzersiz denemesi öncesi $304.0 \pm 74.5 \mathrm{~g}(\% 49.8 \pm 8.9)$, aç egzersiz denemesi öncesi $325.0 \pm 84.1 \mathrm{~g}(\% 50.9 \pm 9.3)$ olup aradaki fark istatistiksel olarak anlamlı değildir $(p=0.214)$. Katılımcıların günlük enerji alım değerleri de sıvı besin alınan egzersiz denemesi ve aç egzersiz denemesi öncesi (sirasıyla 2519.1 $\pm 521.1 \mathrm{kkal} /$ gün ve 2617.8 \pm 462.1 kkal/gün) istatistiksel olarak farklı bulunmamıştır $(\mathrm{p}=0.110)$.

Tablo 3. Aç egzersiz (AE) ve sıvı besin alınan egzersiz (SE) denemeleri öncesi günlük enerji ve besin ögesi alımlarının ortalama ve standart sapma değerleri

\begin{tabular}{lccc}
\hline Enerji ve besin ögeleri & $\mathbf{S E}$ & $\mathbf{A E}$ & $\mathbf{p}$ \\
\hline Enerji (kkal) & $\overline{\mathbf{X}} \pm \mathbf{S}$ & $\overline{\mathrm{X}} \pm \mathbf{S}$ & 0.110 \\
Karbonhidrat (\%) & $2519.1 \pm 521.1$ & $2617.8 \pm 462.1$ & 0.515 \\
Karbonhidrat (g) & $49.8 \pm 8.9$ & $50.9 \pm 9.3$ & 0.214 \\
Protein (\%) & $304.0 \pm 74.5$ & $325.0 \pm 84.1$ & 0.889 \\
Protein (g) & $15.9 \pm 4.7$ & $15.9 \pm 5.6$ & 0.594 \\
Yağ (\%) & $95.1 \pm 26.1$ & $102.7 \pm 48.1$ & 0.726 \\
Yağ (g) & $34.2 \pm 10.5$ & $33.3 \pm 9.8$ & 0.953 \\
\hline
\end{tabular}

SE ön: Slvı Besin Egzersiz öncesi, AE Ön: Aç Egzersiz öncesi. Anlamlılı düzeyi p<0.05 
Tablo 4. Her bir egzersizde kullanılan toplam substrat miktarının ortalama ve standart sapma değerleri

\begin{tabular}{lcccccc}
\hline Değişken & SE1 & SE2 & AE1 & AE2 & p $\neq$ & $\mathbf{p}^{*}$ \\
\hline $\mathrm{RER}_{\text {ort }}$ & $0.94 \pm 0.03$ & $0.90 \pm 0.03 \neq$ & $0.93 \pm 0.02$ & $0.88 \pm 0.02^{*}$ & $<0.001$ & 0.001 \\
KHD $_{\text {top }}, \mathrm{g}$ & $150 \pm 17.9$ & $128.2 \pm 22.4 \neq$ & $146.6 \pm 19.7$ & $115.2 \pm 11.4^{*}$ & 0.002 & 0.001 \\
$\mathrm{YAG}_{\text {top }}, \mathrm{g}$ & $13.4 \pm 6.7$ & $23.9 \pm 7.6 \neq$ & $14.4 \pm 5.1$ & $27.4 \pm 6.0^{*}$ & $<0.001$ & 0.002
\end{tabular}

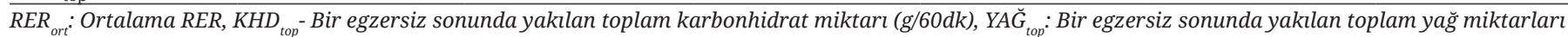
(g/60dk), İstatistiksel olarak anlamlllk $R E R_{\text {ort }}, K_{\text {top }}, Y A \breve{G}_{\text {top }}$ için $p<0.05, p \neq:$ SE1-SE2 arasinda anlaml fark ( $\left.p<0.05\right), p^{*}$ : SE1-AE2 arasinda anlamll fark ( $\left.p<0.05\right)$

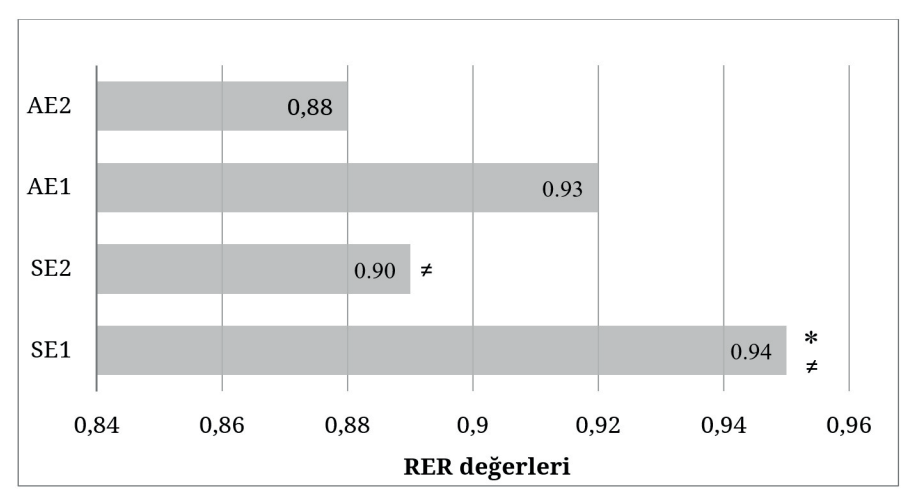

Şekil 1. Ortalama solunum değişim katsayısı (RER) değerleri SE1-SE2(*) ve SE1-AE2 (*) arasinda anlamll fark $(p<0.05)$

Farklı metabolik koşullarda gerçekleştirilen dayanıklılık egzersizi sırasında yakıt kullanımındaki değişiklikler egzersiz sırasında ölçülen RER değerleri incelenerek belirlenmiştir (Tablo 4). Sıvı besin alımı sonrası gerçekleştirilen birinci egzersizdeki (SE1) RER değeri (0.94 \pm 0.03$)$ ikinci egzersizdeki (SE2) RER $(0.90 \pm 0.03)$ değerinden yüksek $(p<0.001)$ olup ikinci egzersizde metabolizmanın yağ oksidasyonu yönüne kaydığını göstermektedir (Tablo 4 ve Şekil 1). Benzer şekilde sıvı besin alınan birinci egzersiz (SE1) sırasındaki RER değerinin, aç durumda yapılan ikinci egzersizdeki (AE2) RER değerinden de yüksektir (SE1 $=0.94 \pm 0.03, \quad \mathrm{AE} 2=0.88 \pm 0.02, \quad \mathrm{p}=0.001$, Tablo 4 ve Şekil 1). Aynı şekilde toplam karbonhidrat oksidasyonu ( $\mathrm{KHD}_{\text {top }}$ ), SE1-SE2 arasinda (SE1 = 150 \pm 17.9 $\mathrm{g} / 60 \mathrm{dk}, \mathrm{SE} 2=128.2 \pm 22.4 \mathrm{~g} / 60 \mathrm{dk}, \mathrm{p}=0.002)$ ve SE1-AE2 arasinda (SE1 $=150 \pm 17.9 \mathrm{~g} / 60 \mathrm{dk}, \mathrm{AE} 2=115 \pm 11.4 \mathrm{~g} / 60$ $\mathrm{dk}, \mathrm{p}=0.001$ ) anlamlı derecede azalmıştır (Tablo 4). $\mathrm{Bu}$ değişime paralel olarak toplam yağ oksidasyonu (YAĞtop) ise SE1-SE2 (SE1 =13.4 $\pm 6.7 \mathrm{~g} / 60 \mathrm{dk}$, SE2= $23.9 \pm 7.6 \mathrm{~g} / 60 \mathrm{dk}, \mathrm{p}<0.001)$ ve SE1-AE2 $(13.4 \pm 6.7 \mathrm{~g} / 60$ $\mathrm{dk}, 27.4 \pm 6.0 \mathrm{~g} / 60 \mathrm{dk}, \mathrm{p}=0.002)$ egzersizleri arasında artmıştır (Tablo 4 ve Şekil 2).

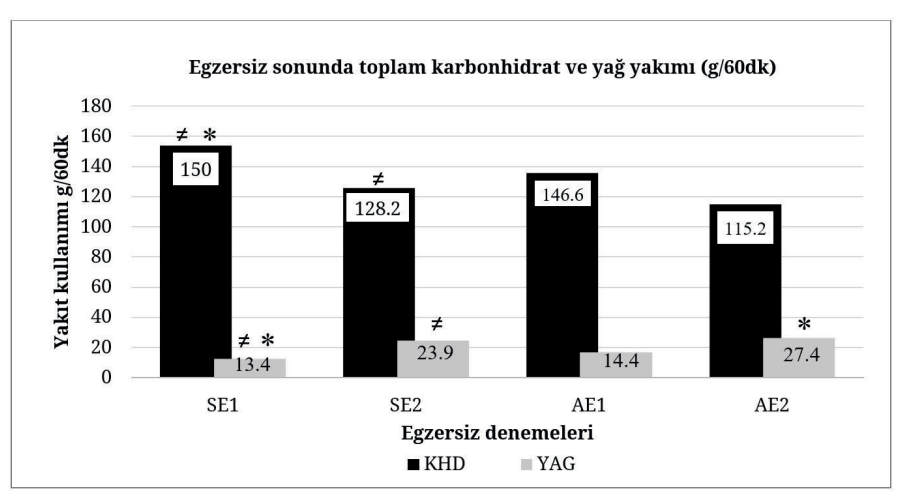

Şekil 2. Egzersizlerde kullanılan toplam karbonhidrat ve yağ miktarı

SE1-SE2( $\neq)$ ve SE1-AE2 (*) arasinda anlamll fark $(p<0.05)$

\section{TARTIŞMA}

$\mathrm{Bu}$ çalışma kapsamında, karaciğer ve/veya kas glikojen depolarının dayanıklılık egzersizi sırasında yakıt kullanımı üzerine etkileri incelenmiştir. Bu amaçla, katılımcılar bir hafta ara ile açlık ve sıvı besin tüketimini takip eden iki farklı metabolik koşulda (sırasıyla karaciğer glikojen depoları boş ve nispeten dolu), aynı şiddette ve $60 \mathrm{dk}$ süren dayanıklılık egzersi protokolünü 1 saat ara ile tekrarlamışlardır. Dayanıklılık egzersizlerinden birincisi, kas glikojen depolarını boşaltma egzersizi olarak planlanırken, ikincisi düşük kas glikojen depoları ile egzersiz yapılmasının yakıt (yağ ve karbonhidrat) kullanımına etkisinin incelenmesine olanak vermiştir.

Katılımcılar seçilirken benzer vücut bileşimi ve aerobik kapasiteye sahip olmalarına özen gösterilmiş, böylece besin alımı ve açlık durumunda gerçekleştirilen egzersiz denemelerinin metabolik yakıt kullanımına etkilerinin objektif koşullarda incelenmesi hedeflenmiştir.

Son zamanlarda dayanıklılık egzersizi ile kas glikojen 
depolarının boşaltılması ve ardından başka bir egzersiz uygulaması modelinin etkilerinin incelendiği çalışmalar, çoğunlukla ikinci egzersiz olarak yüksek şiddetli egzersizlerin (HIT-High Intensity Training) uygulandığı akut egzersiz (20) veya antrenman $(21,22)$ çalışmalarıdır. Bu çalışmaların temel amacı, glikojen depolarının boş olduğu durumlarda egzersiz metabolizmasındaki hücresel, metabolik ve gen düzeyinde oluşan değişimleri incelemektir. Bu çalışmada ise, ikinci egzersizin şiddeti ve süresi birinci egzersiz ile aynı tutularak tüm egzersiz denemeleri arasındaki farkın incelenmesi hedeflenmiştir. Diğer taraftan bu deneysel tasarım ile aynı günde kısa dinlenme aralıklı ard arda iki dayanıklılık egzersiz uygulamasının aç ve sıvı besin alınan durumdaki metabolik etkileri hakkında da yeni bilgilerin ortaya konması öngörülmüştür. Literatürde bu deneysel tasarımla gerçekleştirilmiş bir çalışma bulunmadığından alana katkısının önemli olacağı düşünülmektedir. Karaciğer ve kas dokusu neredeyse tüm vücut glikojen depolarını oluşturmakta ve diyet ile egzersiz bu her iki dokudaki glikojen depo düzeylerini etkileyebilmektedir (23). Karaciğer glikojeninin başlıca kan glukoz düzeyinin korunmasında rol aldığı ve bu yüzden büyük miktarda diurnal değişimler gösterdiği, diyet ile karbonhidrat alımına da yüksek bağımlılığı olduğu bilinmektedir. Karaciğer glikojen deposunun 24 saat açlık sonrası neredeyse tamamen tükendiği, bununda ötesinde sadece bir gece açlı̆̆ın bile karaciğer glikojen depolarını yarı yarıya düşürdüğü, plazma kan glukoz düzeyinin korunmasının neredeyse tamamen glikoneogenez ile karşllanacak düzeye geldiği bildirilmektedir (24). Kas dokusu vücut glikojen depolarının \%80'ini içermekte, bunun yanında dinlenik durumda kas glikojen miktarının çok fazla diurnal farklılıklar göstermediği ve diyetle karbonhidrat alımından çok fazla etkilenmediği belirtilmektedir (24). Diğer taraftan kas glikojeninin, karaciğer glikojeninden farklı olarak 3 günlük total açlık sonrasında sadece $\% 15$, 4. günde ise \%40 azaldığı belirlenmiştir (25).

Bu çalışmanın başlıca bulgusu, kas glikojen depolarının düşük olduğu sıvı besin tüketilen ve aç durumda gerçekleştirilen ikinci egzersizlerde (SE2 ve AE2) yağ oksidasyonunun benzer şekilde arttığının ortaya konmuş olmasıdır. Bu bulguda, egzersiz sırasında yağ kullanımındaki artışta rol alan asıl belirleyici etkenin açlık ya da sıvı besin alımından ziyade kas glikojen depolarındaki azalmadan kaynaklandığını düşündürmektedir. Aç durumda düşük karaciğer ve kas glikojen depoları ile yapılan egzersiz denemesi (AE2) ile normal karaciğer glikojen depoları ve düşük kas glikojen depoları ile gerçekleştirilen egzersiz denemesi (SE2) arasında yağ kullanımında anlamlı farklılık bulunmaması, yağ oksidasyonunda artış hipotezinin kısmen gerçekleşmediğini ortaya koymaktadır. Diğer taraftan, kas glikojen depoları normalken yapılan aç egzersiz denemesinin (AE1) sıvı besin alınan egzersiz denemesine (SE1) göre metabolik yakıt olarak yağ kullanımını, istatistiksel olarak anlamlı düzeyde olmasada, önemli miktarda arttırmış olması yağ oksidasyonunda artış hipotezini kısmen destekleyen bir başka sonuçtur.

\section{Metabolik Yakıt Kullanımı ve RER Değerindeki Değişimler}

Solunum değişim katsayısı değeri üretilen karbondioksitin kullanilan oksijene oranın hesaplanması ile yă̆ ve karbonhidrat yakımı hakkında bize fikir vermektedir. RER değerinin yüksek olması (>1) karbonhidrat oksidasyonunun daha fazla olduğunu gösterirken düşük olması $(<1)$ ise yağ oksidasyonun daha fazla gerçekleştiğini ifade etmektedir (26). Spesifik olarak RER değeri 0.71 arasında değişebilmekte, 0.7 ve 1 değerleri sırası ile baskın olarak yağ ve karbonhidrat kullanıldığını göstermektedir. Birincil olarak yağ oksidasyonunun gerçekleştiği, düşük şiddetli egzersizler sırasında RER değeri tipik olarak 0.8-0.88 arasında değişirken, egzersiz şiddeti yükseldikçe karbonhidrat kullanımının artmasına bağlı olarak RER değeri 0.9-1 bandında gözlemlenir (27).

Egzersiz denemeleri sonrasında RER değerinin SE2 denemesinde SE1'e göre anlamlı bir şekilde azalması, AE2 denemesinde AE1 denemesine göre anlamlı bir azalmanın gerçekleşmemiş (Şekil 1) olması, düşük 
kas glikojen depolarının sadece sıvı besin alınan durumda yağ yakımını etkilediğini göstermekte ve açlık durumunda zaten metabolik olarak artan yağ kullanımına düşük kas glikojen depolarının ekstra bir etkisinin olmadığını düşündürmektedir.

Benzer olarak birçok çalışmada aç yapılan egzersizin yağ kullanımını arttırırken glukoz kullanımını bozmadığı belirtilmektedir (12). Aynı durum toplam yağ oksidasyonundaki artma ve karbonhidrat oksidasyonundaki azalma durumları da RER ile paralel bir şekilde gelişmiştir

SE2 denemesinde toplam yağ oksidasyonundaki artış ve karbonhidrat oksidasyonundaki azalma SE1 denemesine göre anlamlıdır. Diğer önemli bir bulgu ise yağ kullanımındaki artışın ve karbonhidrat kullanımındaki azalmanın SE1-AE1 arasında değil ancak SE1-AE2 arasında istatistiksel olarak anlam kazanmasıdır. Dolayısı ile bu da açlık durumunun değil kas glikojen miktarındaki düşüşün bu farklılıkların oluşmasında başlıca etken olduğunu düşündürmektedir. İnsanlarda egzersiz sirasında kas glikojen düzeylerinin düşmesi ile karbonhidrat kullanımının azalması ve yağ oksidasyonunun artmasının belirgin olduğu saptanmıştır (28). Ayrıca, kısa süreli açlık (12-24 saat) periyotları sonrası yapılan egzersiz ile besin tüketimi sonrası yapılan egzersizin benzer etkiler oluşturduğu (29) ile ilgili bilgiler bulunmaktadır. $\mathrm{Bu}$ veriler ışığında, bizim çalışmamızdaki açlık durumununda egzersiz metabolizmasına etkilerinin sınırlı kaldığı düşünülebilir. Nötr etkisi olduğu ile ilgili bir fikir, SE1 ve AE1 egzersiz denemeleri öncesi dinlenik durumdaki RER değerinin anlamlı derecede farklılık göstermemesi, açlık periyodunun daha uzun olduğu durumda bazı metabolik değişikliklerin oluşabileceğini düşündürmektedir. Gerçekten de, ancak 36 saat ve daha uzun süreli açlık sonrasında plazma substrat düzeyinin 3-4 kat daha fazla arttığı ortaya konmuştur (4).

Sonuç olarak bu çalışma kapsamında kas glikojen depolarının azalmış olduğu sıvı besin alınan ve aç durumda (SE2-AE2) ve kas glikojen depolarının dolu olduğu sıvı besin alınan ve aç durumda (SE1-AE1), substrat kullanımında ortaya çıkan farklılıkların (karbonhidrat, yă̆ kullanımı ve RER'de oluşan değişim) istatistiksel anlama ulaşmaması, bu farkların sadece SE1-SE2, SE1-AE2 arasinda istatistiksel anlama ulaşması açlık tokluk durumunun değil kas glikojen miktarındaki azalmanın bu etkileri oluşturan etmen olduğunu kuvvetli bir şekilde desteklemektedir. $\mathrm{Bu}$ düşünceyi destekleyen bir başka çalışma da kas glikojen depoları düşük durumda iken yaptırılan antrenmanın RER değerini normal denemeye göre azalttığını belirlemiştir (22). Fakat Hulston ve arkadaşları (22) yaptığı bu çalışmada birden fazla egzersiz periyodunun düşük kas glikojen düzeyi ve yüksek şiddetli antrenmanlarla gerçekleştiği ve bunun sonucunda daha düşük bir RER değeri elde edildiği de dikkate alınmalıdır.

$\mathrm{Bu}$ çalışmada ortaya çıkan en önemli bulgu, kas glikojen depolarının düşük olduğu sıvı besin alınan ve bir gece açlık durumundaki egzersizlerde (SE2 ve AE2) benzer şekilde yağ oksidasyonunun artmış olmasının ortaya konması ve buradaki asıl belirleyici etkenin açlık, sıvı besin alım durumlarından çok kas glikojen depolarındaki azalma ile ilgili olduğudur.

Çalışmadaki beklentinin aksine enerji düzeyinin en düşük durumda olduğu AE2 denemesinde SE2 denemesine göre yağ metabolizmasındaki artış ile ilgili anlamlı bir verinin oluşmadığı belirlenmiştir. Bununla beraber, elde edilen bu sonuç birçok kısa süreli açlık (10-12 saat) çalışması ile uyumludur $(12,29)$. Buradan hareketle bundan sonra planlanacak çalışmalarda özellikle açlık periyodu uzatılarak kurgular yapılabilir. Diğer taraftan yeni yapılacak çalışmalarda özellikle yağ kullanımının daha fazla devreye girmesine olanak verecek daha düşük şiddetli ama daha uzun egzersiz modelleri denenebilir. Katılımcıların her türlü aktivite ve beslenme durumlarını kontrol etmek amacı ile metabolik oda türü çalışma planları kullanılabilir.

Bu çalışma kapsamında özetle, kas glikojen depolarının düşük olduğu tok ve aç durumdaki egzersizlerde (SE2 ve AE2) yağ oksidasyonunun benzer şekilde artmış 
oldukları gözlenmiştir. Buna bağlı olarak bu şekilde gerçekleştirilen egzersiz modelinde asıl belirleyici etkenin açlık ve tokluk durumlarından çok kas glikojen depolarındaki azalma olduğunu düşündürmektedir. Diğer taraftan egzersizin glikojen depolarının dolu ve boş olarak uygulanması çalışmalarının sporcu populasyonlarında deneysel boyutta olduğu ve özellikle aç durumda yapılacak egzersizlerde bireyin hipoglisemi başta olmak üzere diğer riskleri kontrol etmeleri gerektiği unutulmamalıdır. Bunun yerine spor diyetisyeni ve spor bilimci ortak planlaması ile, egzersizin yapılabilir ve sürdürülebilir olması bakımından da sedanter gruplarda egzersiz öncesi daha hafif enerji içeren öğün ile yağ oksidasyonunun optimum düzeye getirilmesi hedeflenebilir.

Çıkar çatışması - Conflict of interest: Yazarlar çıkar çatışması olmadığını beyan ederler. - The authors declare that they have no conflict of interest.

\section{KAYNAKLAR}

1. Achten J, Jeukendrup AE. Optimizing fat oxidation through exercise and diet. Nutrition (Burbank, Los Angeles County, Calif) 2004;20(7-8):716-727.

2. Jeukendrup AE. Modulation of carbohydrate and fat utilization by diet, exercise and environment. Biochem Soc Trans 2003;31(Pt 6):1270-1273.

3. Nieman DC, Carlson KA, Brandstater ME, Naegele RT, Blankenship JW. Running endurance in 27-h-fasted humans. J Appl Physiol (1985) 1987;63(6):2502-2509.

4. Zinker BA, Britz K, Brooks GA. Effects of a 36-hour fast on human endurance and substrate utilization. J Appl Physiol (1985) 1990;69(5):1849-1855.

5. Loy SF, Conlee RK, Winder WW, Nelson AG, Arnall DA, Fisher AG. Effects of 24-hour fast on cycling endurance time at two different intensities. J Appl Physiol (1985) 1986;61(2):654-659.

6. Ferguson LM, Rossi KA, Ward E, Jadwin E, Miller TA, Miller WC. Effects of caloric restriction and overnight fasting on cycling endurance performance. J Strength Cond Res/National Strength \& Conditioning Association 2009;23(2):560-570.

7. Gueye L, Seck D, Samb A, Cisse F, Camara K, Martineaud J. Physiological adaptations to exercise during a shortterm fasting. Scr Med (Brno) 2003;76:291-296.

8. Dohm GL, Tapscott EB, Barakat HA, Kasperek GJ.
Influence of fasting on glycogen depletion in rats during exercise. J Appl Physiol Respir Environ Exerc Physiol 1983;55(3):830-833.

9. Knapik JJ, Meredith CN, Jones BH, Suek L, Young VR, Evans WJ. Influence of fasting on carbohydrate and fat metabolism during rest and exercise in men. J Appl Physiol (1985) 1988;64(5):1923-1929.

10. Coyle EF, Coggan AR, Hemmert MK, Lowe RC, Walters TJ. Substrate usage during prolonged exercise following a preexercise meal. J Appl Physiol (1985) 1985;59(2):429433.

11. Civitarese AE, Hesselink MK, Russell AP, Ravussin E, Schrauwen P. Glucose ingestion during exercise blunts exercise-induced gene expression of skeletal muscle fat oxidative genes. Am J Physiol Endocrinol Metab 2005;289(6):E1023-1029.

12. Van Proeyen K, Szlufcik K, Nielens H, Ramaekers M, Hespel P. Beneficial metabolic adaptations due to endurance exercise training in the fasted state. J Appl Physiol (1985) 2011;110(1):236-245.

13. Oliver SJ, Laing SJ, Wilson S, Bilzon JL, Walsh $\mathrm{N}$. Endurance running performance after $48 \mathrm{~h}$ of restricted fluid and/or energy intake. Med Sci Sports Exerc 2007;39(2):316-322.

14. Couturier K BP, Latour MG, Lavoie JM. Evidence that a decrease in liver glycogen content stimulates FFA mobilization during exercise. Can J Appl Physiol 2000;25(3):141-152.

15. Heyward HV, Stolarczyk, L.M. Applied Body Composition Assesment. USA: Human Kinetics;1996.

16. Hawley JA, Noakes TD. Peak power output predicts maximal oxygen uptake and performance time in trained cyclists. Eur J Appl Physiol Occup Physiol 1992;65(1):79-83.

17. Currell K, Jentjens RL, Jeukendrup AE. Reliability of a cycling time trial in a glycogen-depleted state. Eur J Appl Physiol 2006;98(6):583-589.

18. Kuipers H, Verstappen FT, Keizer HA, Geurten P, van Kranenburg G. Variability of aerobic performance in the laboratory and its physiologic correlates. Int J Sports Med 1985;6(4):197-201.

19. Frayn KN. Calculation of substrate oxidation rates in vivo from gaseous exchange. J Appl Physiol Respir Environ Exerc Physiol 1983;55(2):628-634.

20. Yeo WK, McGee SL, Carey AL, Paton CD, Garnham AP, Hargreaves M, et al. Acute signalling responses to intense endurance training commenced with low or normal muscle glycogen. Exp Physiol 2010;95(2):351358. 
21. Yeo WK, Paton CD, Garnham AP, Burke LM, Carey AL, Hawley JA. Skeletal muscle adaptation and performance responses to once a day versus twice every second day endurance training regimens. J Appl Physiol 2008;105(5):1462-1470.

22. Hulston CJ, Venables MC, Mann CH, Martin C, Philp A, Baar K, et al. Training with low muscle glycogen enhances fat metabolism in well-trained cyclists. Med Sci Sports Exerc 2010;42(11):2046-2055.

23. Graham TE, Adamo KB. Dietary carbohydrate and its effects on metabolism and substrate stores in sedentary and active individuals. Can J Appl Physiol 1999;24(5):393415.

24. Hultman E, Bergström J, Roch-Norlund AE. Glycogen Storage in Human Skeletal Muscle. In: Pernow B, Saltin B, editors. Muscle Metabolism During Exercise. Advances in Experimental Medicine and Biology. 11: Springer US; 1971. p. 273-88.

25. Hultman E, Bergstrom J. Muscle glycogen synthesis in relation to diet studied in normal subjects. Acta medica
Scandinavica 1967;182(1):109-117.

26. Ramos-Jiménez A, Hernández-Torres RP, Torres-Durán PV, Romero-Gonzalez J, Mascher D, Posadas-Romero C, et al. The respiratory exchange ratio is associated with fitness indicators both in trained and untrained men: A possible application for people with reduced exercise tolerance. Clin Med Insights Circ Respir Pulm Med 2008;2:1-9.

27. Deuster PA, Heled Y. Chapter 41 - Testing for Maximal Aerobic Power A2 - Seidenberg, Peter H. In: Beutler AI, editor. The Sports Medicine Resource Manual. Philadelphia: W.B. Saunders;2008. p. 520-8.

28. Blomstrand E, Saltin B. Effect of muscle glycogen on glucose, lactate and amino acid metabolism during exercise and recovery in human subjects. J Physiol 1999;514( Pt 1):293-302.

29. Schisler JA, Ianuzzo CD. Running to maintain cardiovascular fitness is not limited by short-term fasting or enhanced by carbohydrate supplementation. J Phys Act Health 2007;4(1):101-112. 